\title{
Lidar-Based Detection and Interpretation of Glaciotectonic Features of the Morainic Topography of Finland
}

\author{
Matti Veli Juhani Seppälä \\ Soil Laboratory of Oulu City, PL 78, 90015 Oulun kaupunki, Finland \\ Correspondence should be addressed to Matti Veli Juhani Seppälä; matti.seppala@ouka.fi
}

Received 26 April 2016; Revised 6 September 2016; Accepted 12 October 2016

Academic Editor: Karoly Nemeth

Copyright ( 2016 Matti Veli Juhani Seppälä. This is an open access article distributed under the Creative Commons Attribution License, which permits unrestricted use, distribution, and reproduction in any medium, provided the original work is properly cited.

\begin{abstract}
In Finland's digital elevation model, marks of glaciotectonics as an important formation process of glacial geomorphology can be seen. This is a new finding to this extent regarding central parts of the former ice sheets. Deformational processes produced fragmented till surfaces probably mostly by brittle fracture of frozen till. Good signs of deformational effect to the till surfaces are the plucked edges or steps and semilinear or fan-like quarry edges in topography, which are often oblique compared with the main direction of the flow of the glacier. Plucked fractured steps of blocks of till can be so tight that they construct horizontal-like diamond patterned surfaces. Sometimes punctate proximal endings of fan-like hollows of transported rafts can be seen. Within main ice lobes or streams the glaciated terrain is often divided into longitudinal smooth looking drumlin terrain and into rough erosional slightly lower level situated zones, where the erosion has happened firstly by glaciotectonism and then by glaciofluvial streams. The eskers and different kind of hummocky moraines are often located in same zones. Among them deformational hummocky moraines and ribbed moraines are common. The abundance of glaciotectonic and plucking related features indicates that the base of the receding ice sheet was cold based in places or from time to time.
\end{abstract}

\section{Introduction}

Glaciotectonics refers in this study mostly to the erosional deformation of the former till layers or moraines at the base of the active glacier. The glacier can probably move frozen blocks of till and cause so faults and fragments and irregular erosional looking topography. Glaciotectonism is capable of producing a broken looking cover or ground moraine and a variety of other deformational moraines and surface features. The main process flow has been detachment of the till block, transport, and deposition. These processes can be purely glaciotectonic but block plucking or refreezing of meltwater is assumed to take part in the activities to some extent. Several researchers advocate that glaciotectonism is more closely associated just with the mechanical forces caused by the weight and movement of the glacier [1-6].

For practical reasons I however use here mostly the broad term of glaciotectonic so that it includes a possible freezing process and in terms of landforms or moraines it only relates to the process which contributes to shaping the landform, in the majority of cases presumably by brittle deformation and removal of the frozen block of till, or by glaciotectonic ductile deformation and remoulding of the primary landform (cf. [7] p. 379 and 459). Close terms are push moraines [8], thrust-block moraines [7, 9], ice-thrust moraines, and related hummocky moraines (e.q. [10-15]). In general, those terms are used for the marginal or submarginal environment and along Aber's glaciotectonism model of glaciotectonic constructive landforms; hill-hole pairs, composite ridges, thrustblock moraines, mega blocks, push moraines, and cupola hills are originally marginal formations [16]. Here glaciotectonism concerns the subglacial environment as well and in practice almost exclusively. Glaciotectonic literature deals largely with large scale ice-marginal landforms consisting often partly of sedimentary rocks near the terminal zones of the former ice sheets [17]. In this case, research focused on glaciotectonic deformation effects of otherwise quite low profile morainic morphology interpreted by DEM in the intermediate parts of the former ice sheet. 
Morphologically lidar-based research about glacial geomorphology of the former ice sheets is rapidly increasing concerning morphology of some glacial lineations, end moraines, hummocks, and eskers [18], but so far the research focus has been elsewhere than glaciotectonics: ice stream and lobal patterns, drumlins, ribbed, hummocky and marginal moraines, glaciofluvial formations, or postglacial faults and other topics of surficial geology. Precise DEMs reveal a much more detailed image of glacial landforms than previous corresponding methods. Möller and Dowling [19] examined in Småland also the geology of irregular morainic morphology besides streamlined formations, but there hummocky moraines and ribbed moraines are deduced to have built up mostly in stagnant-ice landsystem, but I think presumably there could also be at places a short active glaciotectonic stage or zone with partly or intermittently frozen bed conditions in lowered marginal zone of the retreating glacier (cf. [20]). The glacial geomorphology has been mapped also as lidarbased interpretation and with ice-thrust features in Canada (e.q. [21]).

\section{Materials and Methods}

The present research is based on the visual interpretation of the elevation model in grid size $2 \mathrm{~m} \times 2 \mathrm{~m}$ of the National Land Survey of Finland. It is freely available for download as laz, asc, and tiff data files. The elevation is shown for about $0.3 \mathrm{~m}$ accuracy. The files are viewed online or with free graphics and GIS software. Programs can visualize morphology by oblique shaded height models. Not any morphometric or other GIS analyses have been done except some height profile diagrams. Online maps by the National Land Survey of Finland and online service for DEM and geological data by the Geological Survey of Finland are also used.

During the investigation, I examined basically randomly the topography of mainly known moraine areas in different parts of the country [22]. Finland's whole land area is $303892 \mathrm{~km}^{2}$ and statistically about half of that was viewed with at least $1: 16000$ scales. So it is obvious that many types of fragmented morainic topography of Finland are detected, but there can be some which are not observed yet. The premise was to find broken, fragmented, or "excavated" forms, which could be interpreted with good reason to be related to the glacigenic block erosion of preexisting landforms. In practice it seems that these features can be detected just in most accurate DEM2 (2 $\mathrm{m}$ grid), when testing the DEMs now freely available by the National Land Survey of Finland (Figure 1). The aim of the study was to find deformational or glaciotectonic features in DEMs and so in nature, too. The locations of the example figures of the features can be seen in Figure 2 .

\section{Results and Discussion}

3.1. Plucked Lee Side. Plucking of the (frozen) till seems to be quite a common phenomenon in the lee sides of the morainic hills, drumlins, and moraines (Figures 3, 4, and 5). The dimensions vary considerably. In Figure 3 the plucked

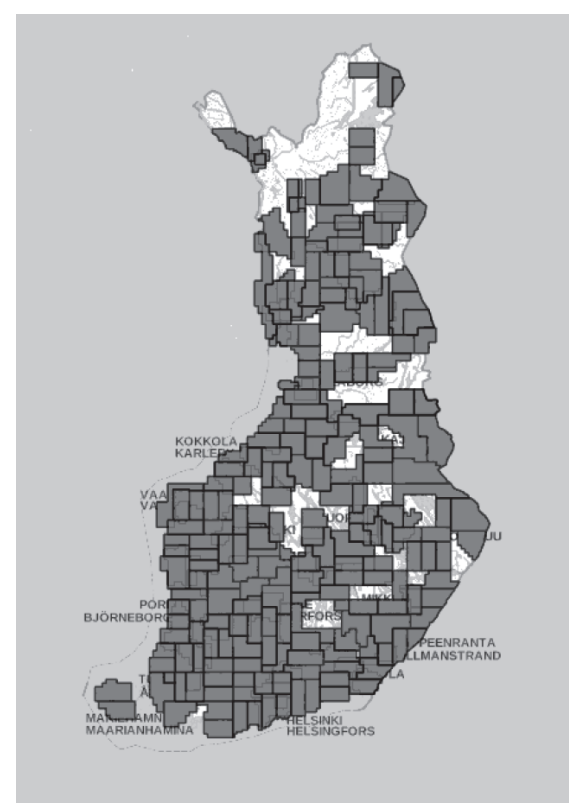

FIGURE 1: Airborne laser scanned areas 2008-2015 (C National Land Survey of Finland).

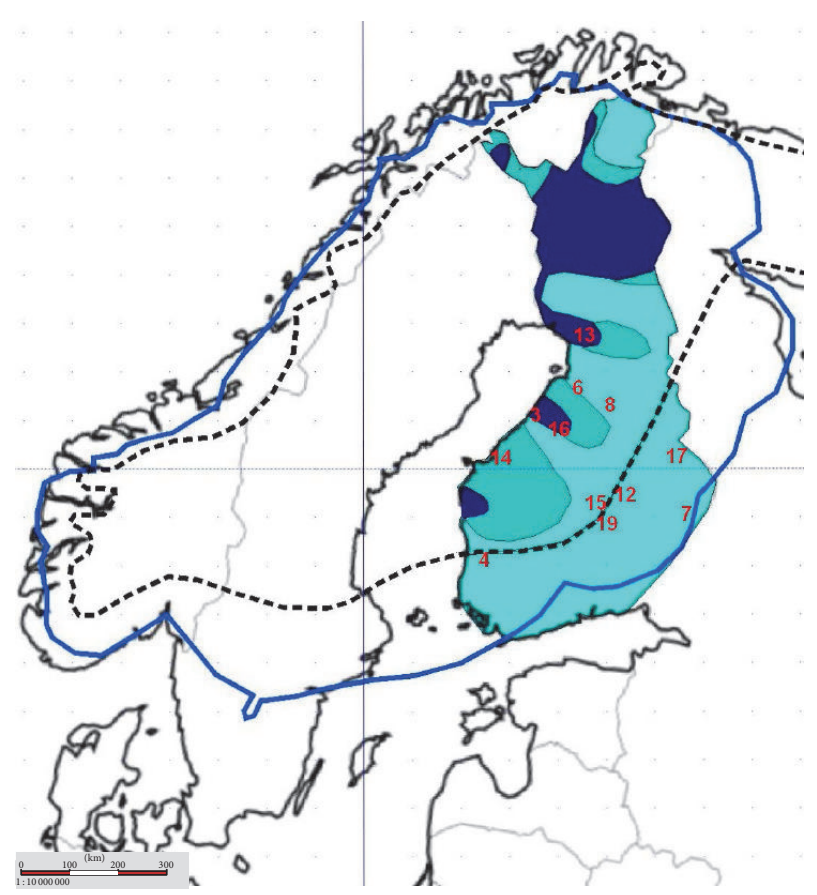

FIGURE 2: Locations of the sites, for example (red numbers refer to the Figures) of glaciotectonic landforms and possible glaciological boundaries for frozen bed conditions in Finland, during Last Glacial Maximum (cross-line) and during final local deglaciation (dark blue area) with diminishing frozen bed areas (grey) around areas marked with dark blue, when deglaciation progressed after Younger Dryas. Younger Dryas ice margin marked with blue line (modified from Stroeven et al. 2016 [23]: Figure 4).

section is, for example, 1-3 m high, $100 \mathrm{~m}$ wide, and $350 \mathrm{~m}$ long excavation within a $15 \mathrm{~m}$ high ridge. But the size of the 


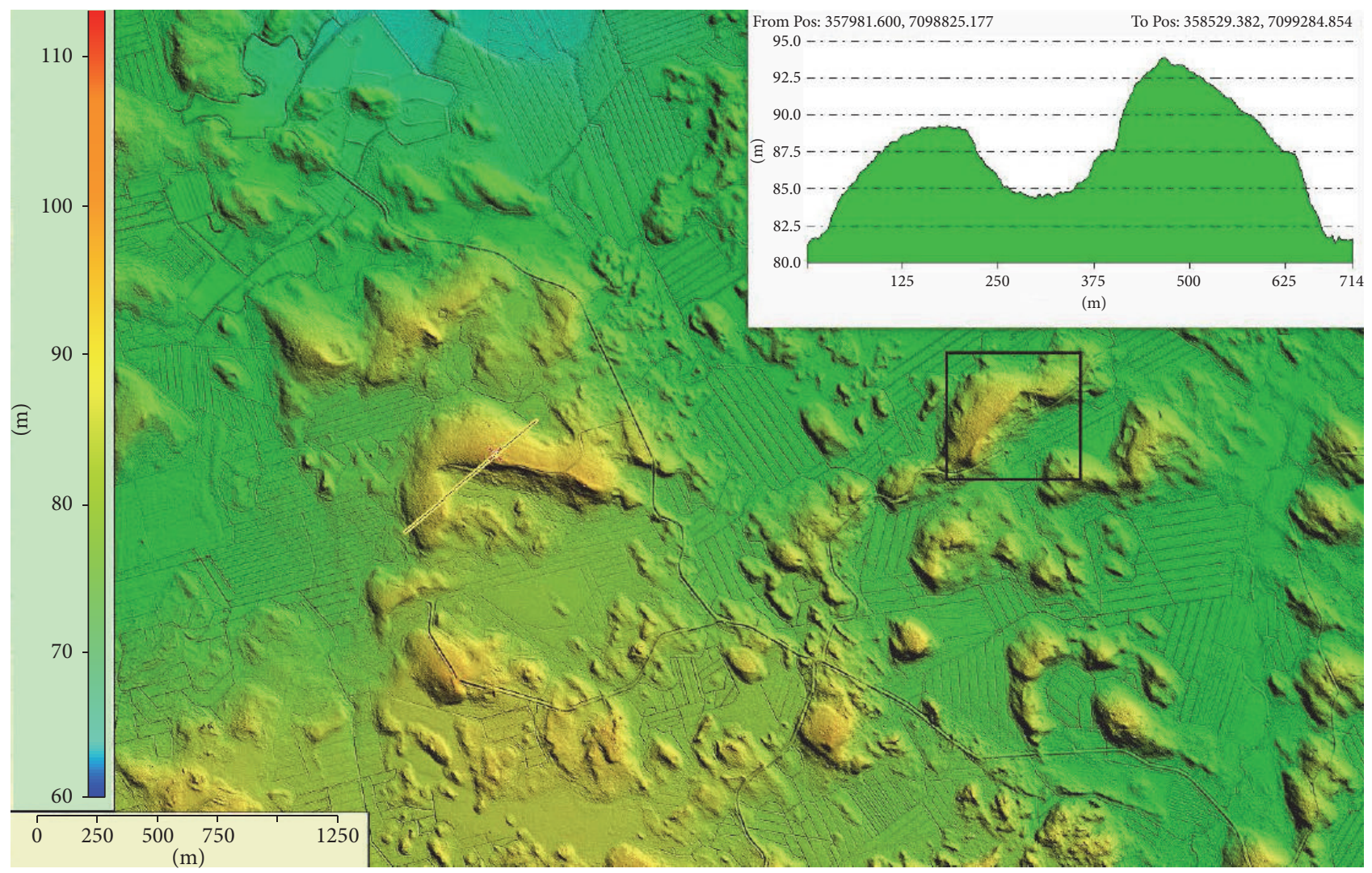

Figure 3: Plucked surface features and ribbed moraines. One plucked lee side consisting of till is marked by the square. The profile is perpendicular to the prevailing ice flow direction. The height in profile has been highlighted. Susineva, Kalajoki (Map sheet Q4231A, (C) National Land Survey open data 02/2015).

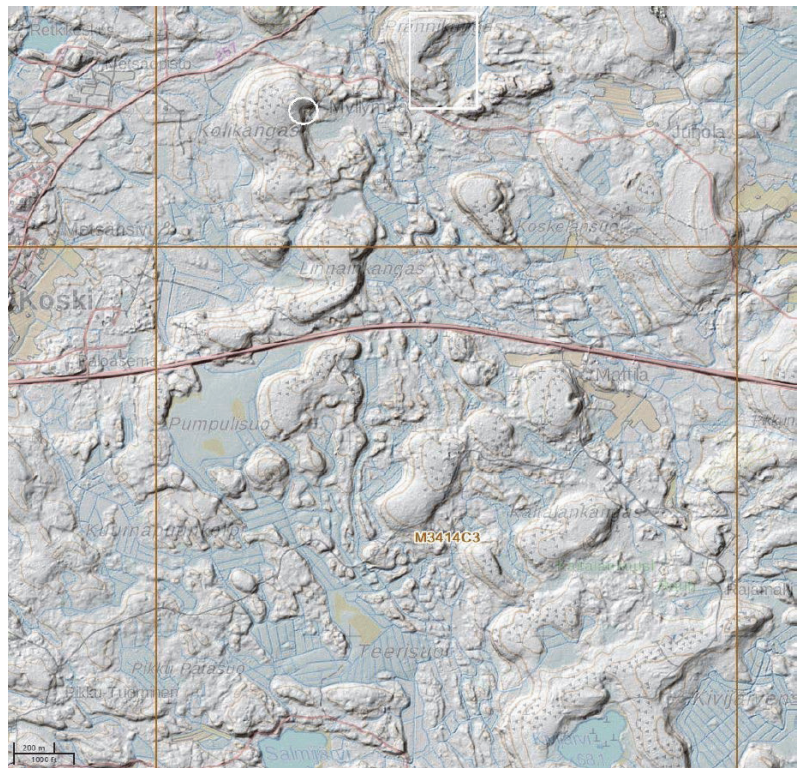

Figure 4: Plucked lee sides and other glaciotectonic features in Kullaa, Pori region. One plucked lee side is marked by the square and location of the photo (Figure 5) is marked by the circle. The height difference of the uniform contour lines of the base map is $5 \mathrm{~m}$ (Map sheet M3414C, (c) National Land Survey).

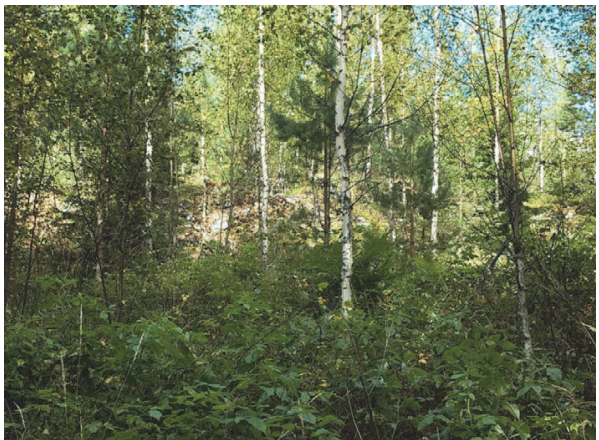

FIGURE 5: A terrain photo of plucked lee side of Kolikangas in Koski village, Kullaa, in Pori region (cf. Figure 4).

removed blocks can be at maximum almost as much as the size of ridges. One cannot usually say certainly where the removed blocks of till have gone. Plucking can affect the distal sides of some transverse or marginal moraines. The plucking lines are then often quite straight and transversely oriented with respect to the glacier flow direction, but plucked hollows and their edges can come in many shapes. Method of formation is possibly analogous to the creation of Roche 


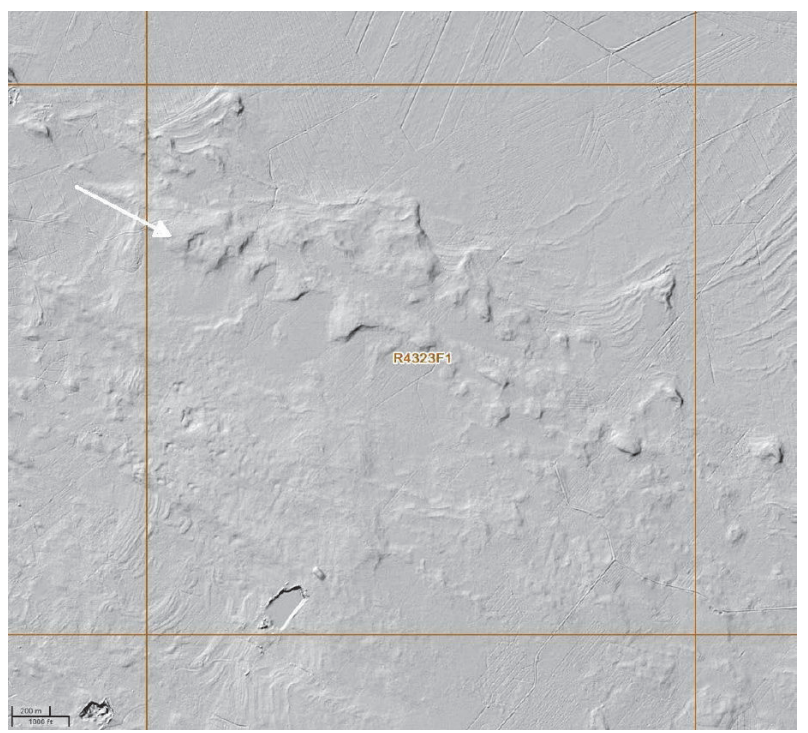

FIgURE 6: Like low, 1-3 m high, subglacial hill-hole pairs or drag marks in Tyrnävä. The arrow shows the pathline of displacements and ice flow direction (Map sheet R4323F, (C) National Land Survey).

Moutonné formations with the difference that the process is directed to the (frozen) till and not to the bedrock, and size class of subglacial bumps (primary moraines) is often greater than what is presumed for normal bedrock plucking: pressure melting leads to the development of water on the stoss side. Then the water flows to the lee side and there freezes at a minimum pressure again. New layers of the basement can freeze to the glacier and get being involved in the transport [7, 24]. Boulton [25] regards it possible that subglacial plucking of till blocks can act with frozen sediments. There it can also develop faults and fractures in basal frozen till bed like joints in bedrock, which contribute plucking processes (cf. [26, 27]).

Kleman and Borgström ([28], cf. [29]) presented the term (transverse) lee side scarp for the landform, which had formed along them under moving ice at the distal end of the basal frozen patch, which is situated on the quite big hill in northern Sweden at or near the ice divide area in the mountains. Normally smaller "plucked lee sides" are not regionally so specialized in Finland.

3.2. Hill-Hole Pair. Hill-hole pair consists of ice-scooped basin and ice-shoved hill. So it is the basic glaciotectonic landform type where the depression, transportation, and resulted hill are represented [6]. In Finland this basically marginal landform is however probably a very rare phenomenon with the exception of ribbed moraines, if they are created as fragments of the former till beds ([30], cf. [20, 31-36]). One minor possible subglacial example can be viewed in Figure 6. In fact, it is the best candidate for hill-hole pair so far that I have discovered in the DEM of Finland. The height of the shape is $1-3 \mathrm{~m}$. An example of possible ice-marginal thrust type hill-hole pair is represented in Figure 7.

3.3. Fan-Like and Transverse Edges of Plucked Depressions. In northeast Manamansalo occurs one characteristic type

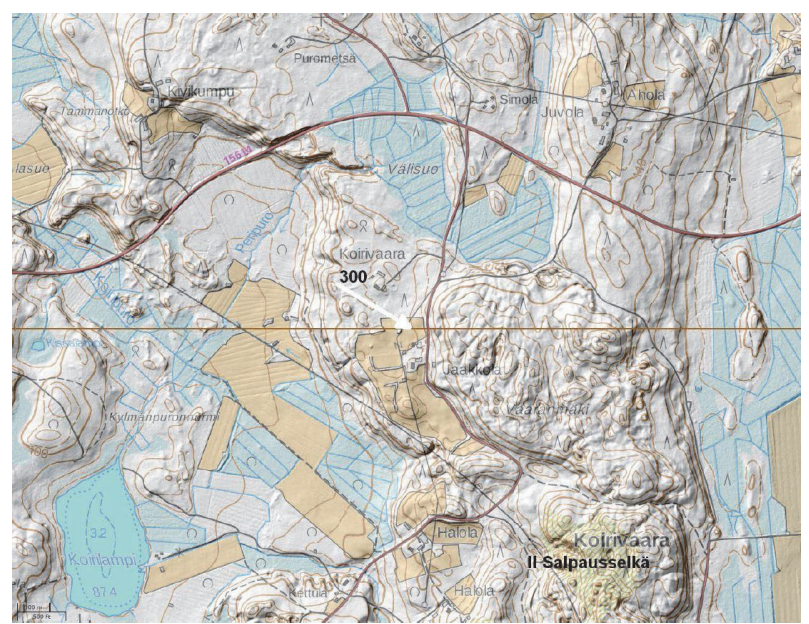

FIGURE 7: An ice-marginal possible hill-hole pair on II Salpausselkä line (N-S course), south of Joensuu in North Karelia. Along the general map of surface geology (Geological Survey), the material of the hill and surroundings consist mostly of glaciofluvial drift, but the bottom of the hole is morainic. The imagined displacement direction is the same $\left(300^{\circ}\right)$ as the direction of small drumlins, which presumably show last prominent ice flow direction at the place. The height difference of the uniform contour lines of the base map is $5 \mathrm{~m}$. So that hole is about $25 \mathrm{~m}$ deep. (Map sheets N5431H, N5432G, (C) National Land Survey).

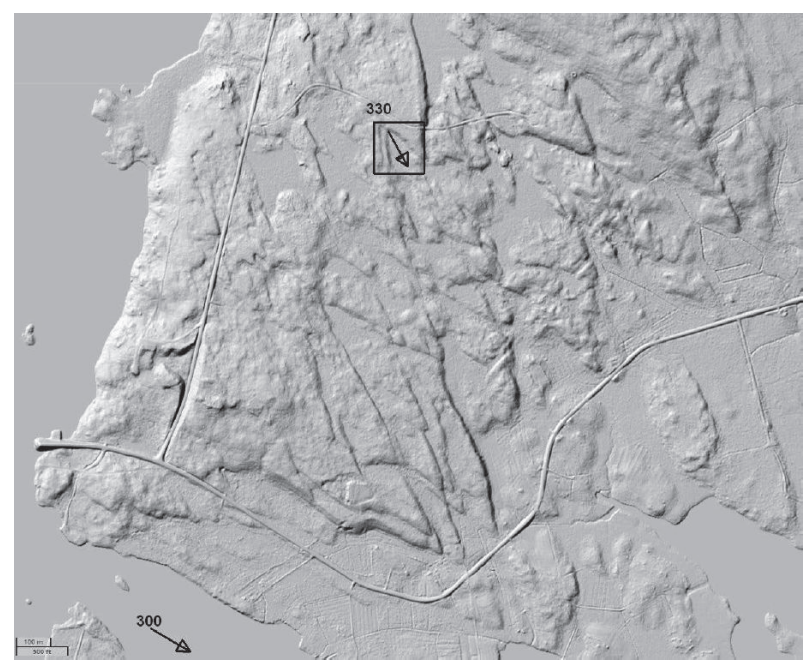

FIGURE 8: Fan-like hollows of plucked or glaciotectonic rafts with some punctate proximal endings in the Oulujärvi Region, Kaivanto (Map sheet Q5222D, (C) National Land Survey). One fan-like hollow with ice flow direction $330^{\circ}$ marked. The general ice flow direction is $300^{\circ}$. The edge height of hollows is generally about $1-3 \mathrm{~m}$.

probably plucked shape, which can be called a fan-like hollow of glacial raft or fan-like edges and steps of plucked hollow in the till bed (Figures 8-11). It has a punctuate proximal ending from where the sides of the fragment open with a fan-like manner in the distal direction. This is obviously a predominantly brittle fracture of the frozen moraine block. The opening angle is about 35 degrees, and the directions 


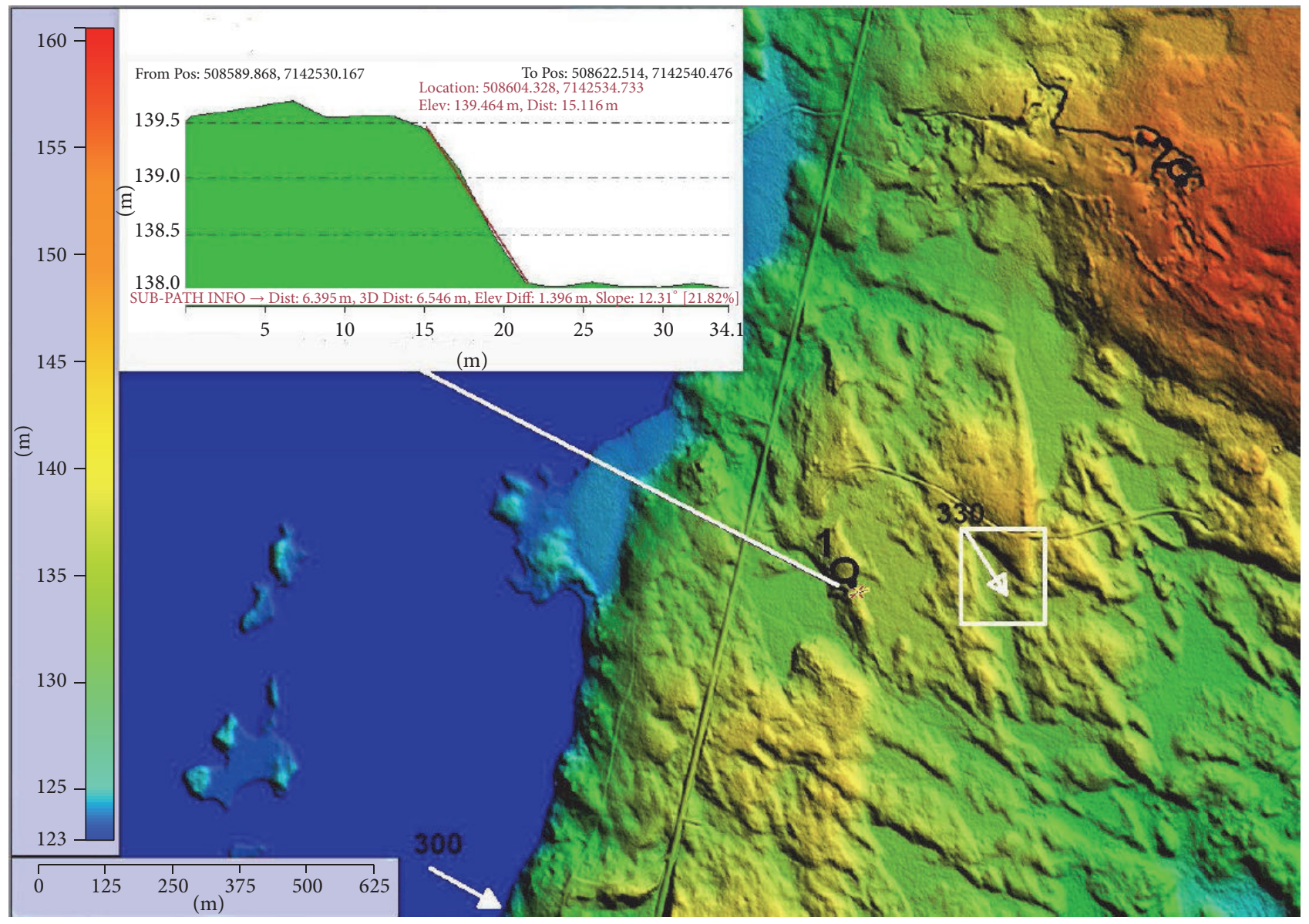

Figure 9: Places of terrain photos 1 (Figure 10) and 2 (Figure 11) and a profile from the photo place 1. The ice flow directions are like shown in Figure 8.

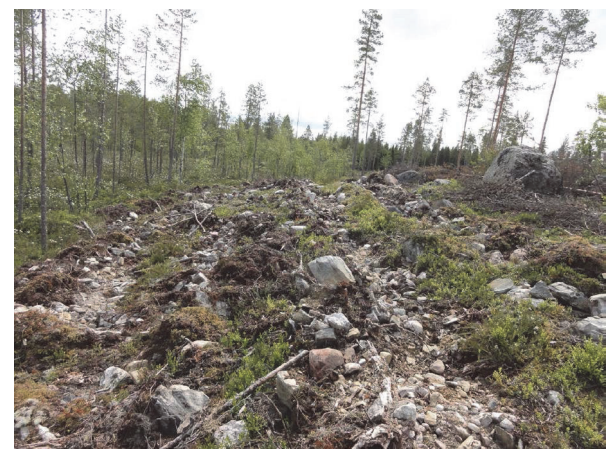

Figure 10: A terrain photo showing place 1 in Figure 9: the edge of a fan hollow. The shooting direction is towards southeast.

of the fans vary, 120-150 degrees, which are more northern than the main direction of the striations in the Oulujärvi region. The opening angle can still get a lot broader, too. Sometimes both sides of the hollow can be seen; sometimes only other side is in sight or formed. There are also variants

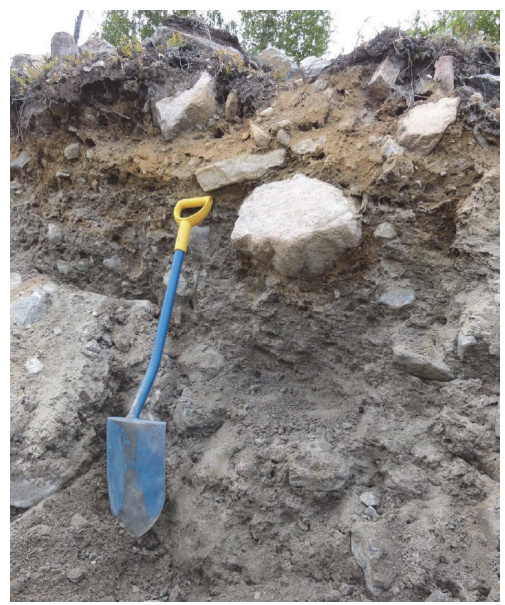

FIGURE 11: A terrain photo showing a moraine excavation in place 2 of Figure 9. The overall nature of the ground moraine in the surroundings: grey sandy basal (lodgment) till with quite massive and compact structure and looser brown surface layer with plenty of boulders. The direction of the trench wall is approximately from west to east. 


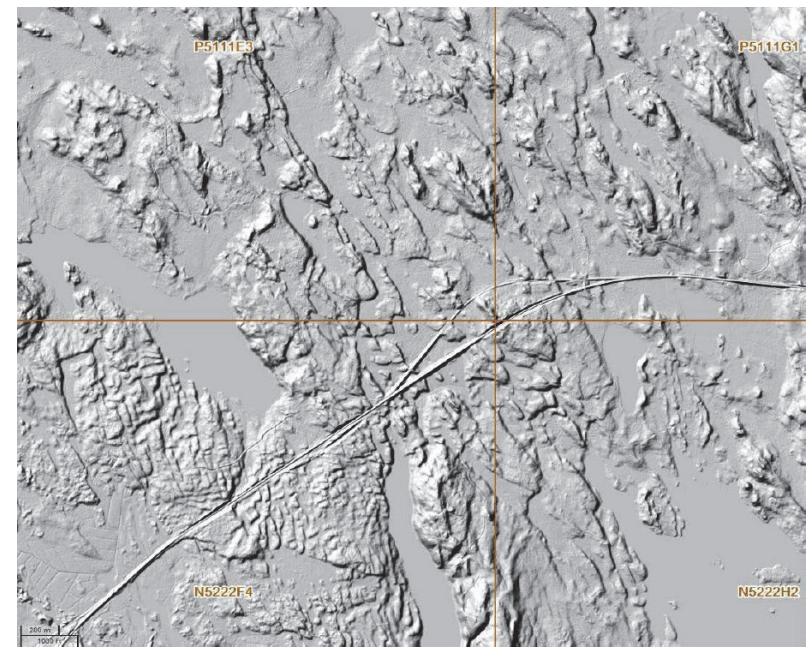

FIGURE 12: Glaciotectonically fragmented morainic topography near Kutunjärvi in Savo. Edges of fan-like hollows produce diamondpatterned surfaces. Ice flow direction is from the northwest () National Land Survey).

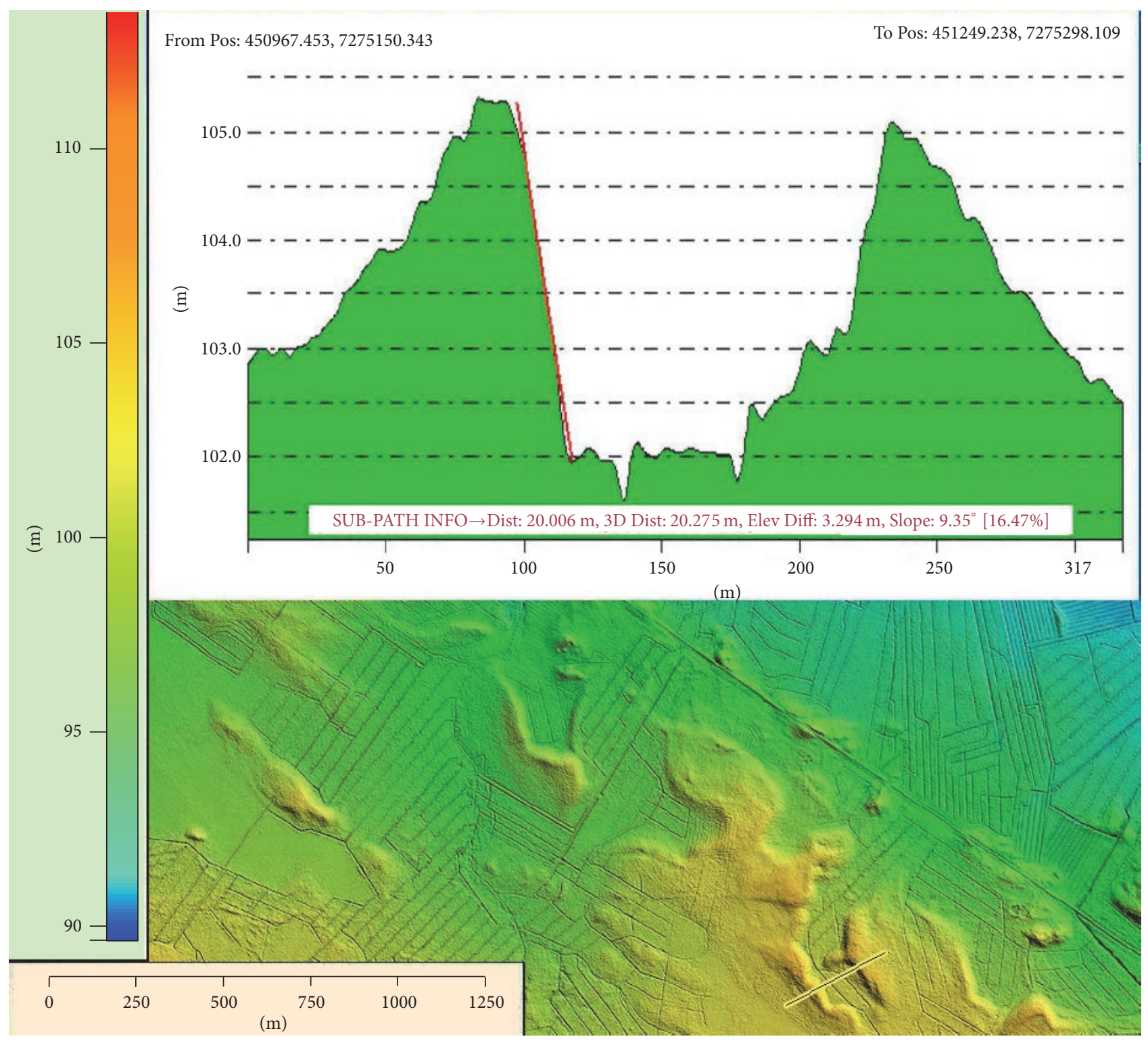

FIGURE 13: Sporadic plucked hollows near Oijärvi. The shapes are rectangular. The maximum height of the quite steep (slope, e.g., 9,35 ${ }^{\circ}$, the profile height is strongly exaggerated) edge is in profile 3,3 m (Map sheet $\mathrm{S} 4323 \mathrm{H}$, (c) National Land Survey). 


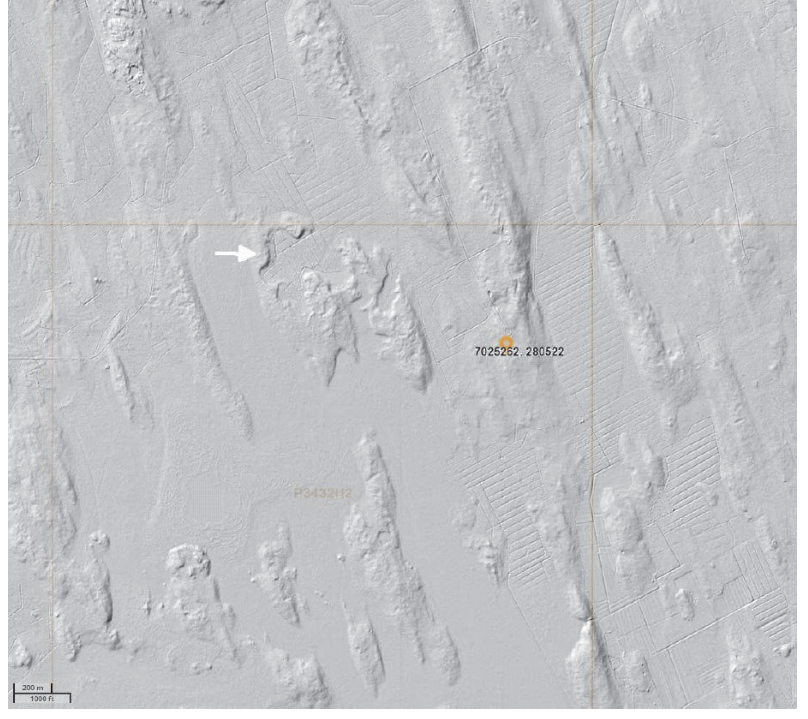

FIGURE 14: Sporadic plucked hollows from western Finland's coastal region, Vöyri. There are many minor pits in drumlins and some bigger probably glaciotectonic subglacial excavations of which one is marked with a white arrow (@ National Land Survey).

with wider round proximal endings. Dimensions can vary significantly. The shapes can also be stacked and overlapped. Representative quarries' heads have a diameter of about $30 \mathrm{~m}$ and an edge length of about $500 \mathrm{~m}$. Often the detectable maximum length and width are in the order of $50-200 \mathrm{~m}$. The depth of the shape is often 1-3 $\mathrm{m}$ and can be even $5 \mathrm{~m}$ at the proximal end. The sides of the fan-like hollows are slightly curved but roughly quite straight lines. Their steepness varies slightly and in some places, they tend to rise to the low ridge. In Figures 10 and 11 can be seen photos of local terrain and till exposures in Kaivanto.

The edges of fan-like hollows are as a general rule oblique in relation to the flow direction in which they are formed. Plucked edges of fragments can also be more straight and then often transverse in relation to the flow direction. Tightly spaced fan-like fragment lines produce diamond patterned moraine surfaces (Figure 12). In some places, faults produce rectangular grid patterns. It can happen because transverse faults are interleaved with fan-like faults. The faults in the bedrock can also be evolved and confused with morainic features.

3.4. Sporadic Plucked Hollows. The quarried lee side is likely the most common special case of plucked blocks of moraine stratum, which the glacier has overridden. There are also plucked hollows in sporadic places of landforms. These are often smaller in size. The shape of these features varies, but they are typically surprisingly angular. For instance near Oijärvi can be seen quite rectangular hollows in DEM (Figure 13). In Figure 14 can be seen many capture hollows in drumlins. In some areas, there are plenty of glaciotectonically plucked hollows in glaciodynamic landscape and in other areas the original smooth shape has preserved.

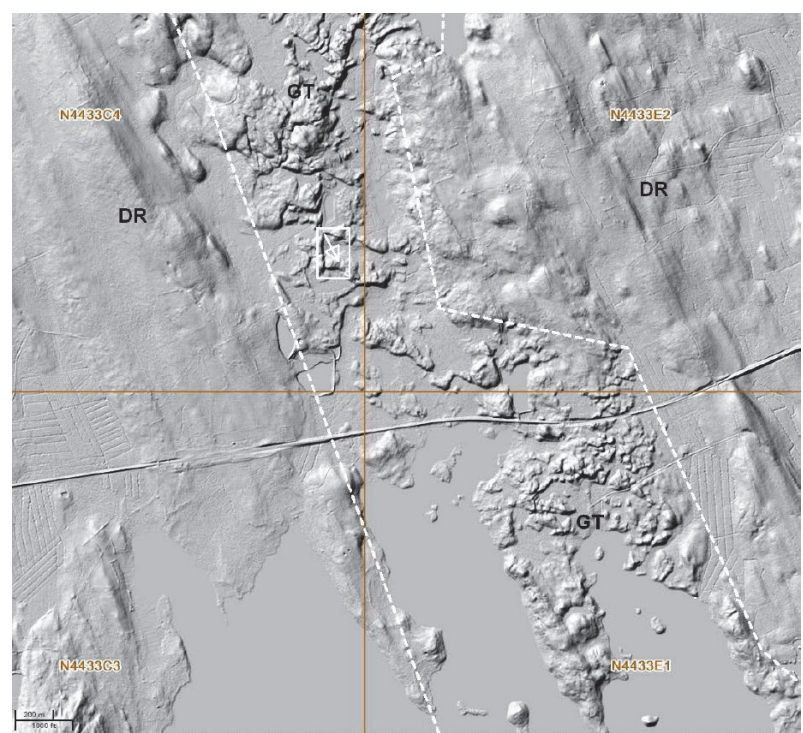

FIGURE 15: Morphologically defined glaciotectonic (GT) hummocky moraine with fan-like hollows in low longitudinal bedrock depression between smooth drumlin (DR) fields. Venetmäki, Pieksämäki. One fan-like fragment with ice flow direction marked. Fragmentary hummocks and fan edges are about $2-15 \mathrm{~m}$ high varying the size and shape significantly. Steepness of the slope may be, for example, $22^{\circ}$. The valley with irregular surface features lies about 20-30 m lower in level than drumlin terrain. (Map sheets N4433C, E; (c) National Land Survey).

3.5. Deformational or Glaciotectonic Mound or Ridge. Logically, the group responsible for this form of a sort of hill-hole pair hill parts without the clear original hollows. Single hill part is difficult to recognize, but also whole plucking and glaciotectonism related fields of mounds or ridges could be generated in a similar manner. Mainly glaciotectonic hummocky (ribbed) moraine, shear moraine, thrust moraine, push moraine, and end moraine might come into question (cf. [12]). There are in Figure 15 deformational hummocky moraines, figuratively speaking e.q. tile moraines. The distinctive feature would refer to the secondary erosion characteristics: many kinds of plucked edges of moraine. Jigsaw type of ribbed moraine is one presentable example of at least partly fragmented moraines [30]. There are also clues about glaciotectonic submarginal moraines (Figure 16). The major marginal moraines at Salpausselkä line could at some supra-aquatic or low water areas also have ice-thrust features as judged by stricter climate at the Younger Dryas, when there were favorable conditions for the preservation of proglacial permafrost (Figure 7, cf. [37-39]). In Figure 17 there occurs a landform assemblage, which can be used to interpret partly the age order of different formations. The age order from older to younger could be big drumlins, glaciotectonic hummocky moraine, esker, and flutes, although the last three are all quite late and almost coeval deglacial formations.

3.6. Distribution and Genesis. The purpose of this study was not to map and explain exactly the distribution of glacial deformation related or glaciotectonic features in Finland, but 


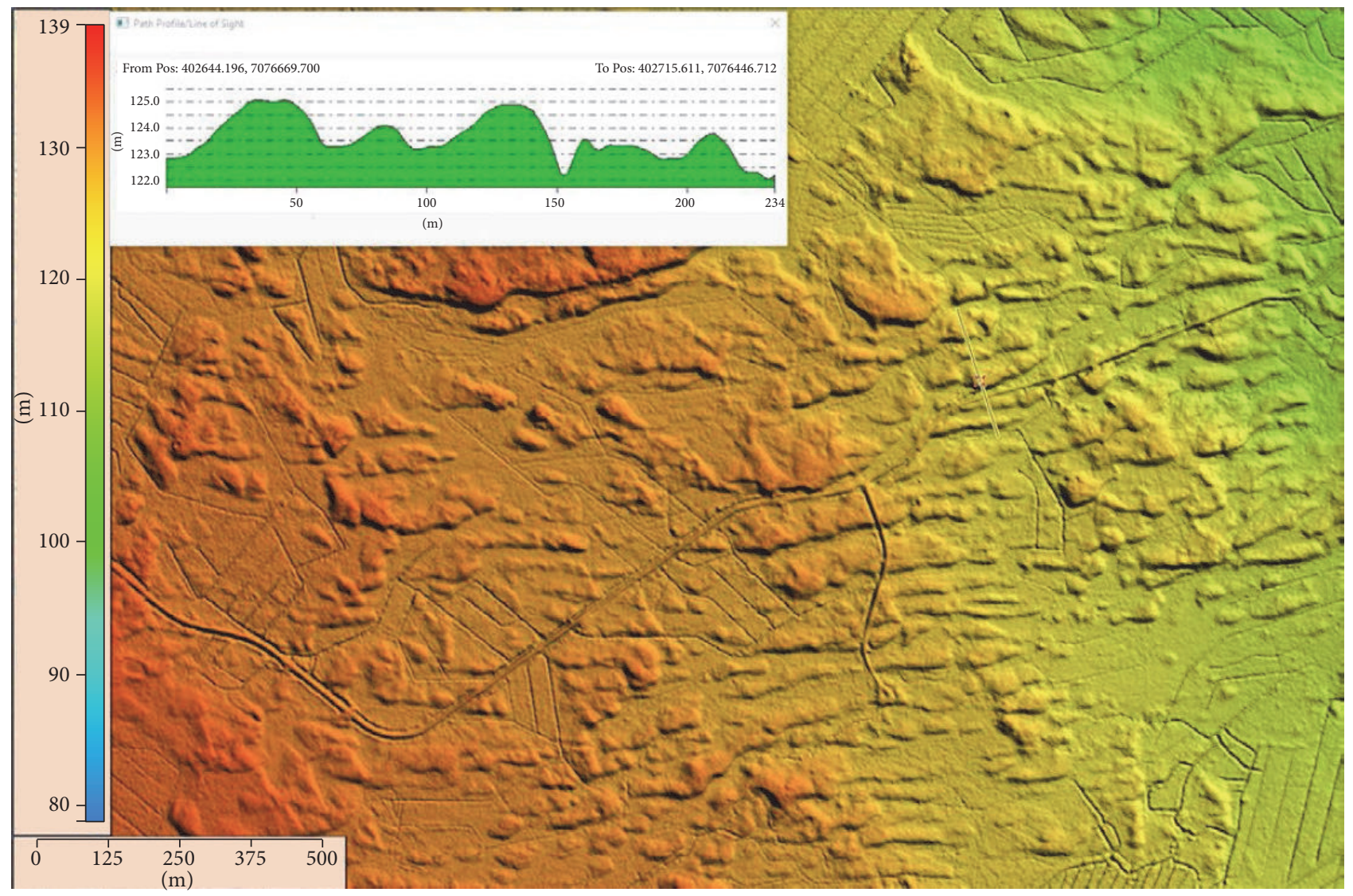

Figure 16: Probably glaciotectonic submarginal moraines in Nivala near the old mine of Makola (@ National Land Survey).

some general outlines can be drawn about that, too. Firstly it seems that deformational features are abundant in the same areas, where there occur plenty of ribbed moraines: Pori region, southern Lapland, and Central Ostrobothnia. For the last two areas, the explanation could be that they situated near the ice divide during the Last Glacial Maximum. The base of the glacier could be frozen until the deglaciation time, when the warm inner marginal zone moved inward to the place and the jigsaw ribbed moraines fragmented at the thermal and dynamic transition zone, when the glacier base began to slide there [30]. Pori region and some other southern ribbed moraines and glaciotectonic features having areas were not so centrally situated in relation to the ice divide and there could be at times cold zones nearer to the retreating margin. The effect of glaciotectonic deformation can be seen notably for instance on the following hummocky moraine fields of Finland ([22], Figures 11 and 29) and on their surroundings: (1) Pori-Ahlainen, (2) Kalvola-Renko, (3) Lammi-Padasjoki, (4) Loviisa-Kotka (5) Mäntyharju, (6) Vaasa-Maksamaa, (7) Kälviä-Kivijärvi, (8) Kalajoki-Pihtipudas, (10) Toivakka, (11) Etelä-Savo, (12) Leppävirta, (16) Kajaani-Outokumpu, (19) Oulu, (20) Puolanka-Vaala, (21) Kuhmo, (23) Sihtuuna, (24) Ranua, and (25) Kemijärvi. Location numbers (original field numbers) refer to Figure 18. Of course, there are glaciotectonic features also outside those hummocky moraine fields.

Within main ice lobes or streams like in Lake Finland, Savonia, North Karelia, and Kainuu the glaciated terrain is often divided into smooth looking drumlin highlands and into radial rough erosional lowland zones, where the erosion has happened firstly by glaciotectonism and plucking and then by glaciofluvial streams (Figure 19). The elevation difference between smooth and rough zones is related to the local relief, but it is typically about $5-50 \mathrm{~m}$. So differentiation can happen between almost level areas. Eskers and different kinds of hummocky moraines are equally situated often in the same zones. In eastern Finland's hilly landscape there are in some areas glaciotectonic or plucking related looking hummocky moraines at the lee side slopes. In valleys can occur other hummocky moraine types too.

Glaciotectonic and plucking features are probably connected to the warm/cold and cold/warm transition zones at the glacier base like cold interior parts of the ice sheet, frozen bed patches or sticky spots between ice streams and at their onset areas, and at possible cold margins (e.g., [20, 4043]). The exact nature of longitudinal rough zones between smooth drumlin swarms is still quite unclear. Maybe they are just zones, where there was slower ice motion, more glaciofluvial drainage and temporary freezing and plucking, and postglacial drainage. All that mostly because of the thermal and dynamic regime of the retreating ice sheet.

Subglacial moraine block erosion can occur extensively (1) during the same polythermal flow stage, (2) related to the retreating and proceeding in different flow stages or glaciations, and (3) during minor oscillations of the margin. 


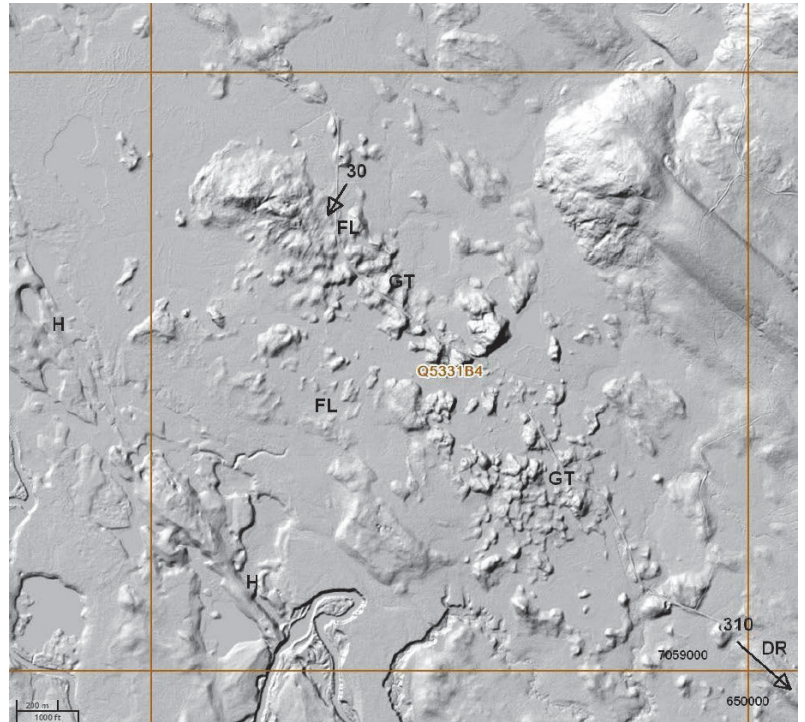

Figure 17: In the DEM extract from eastern Finland, Nurmes, nearly mega scale glacial lineations can be seen, big drumlins (DR), by the look of it glaciotectonic hummocky moraine (GT), esker $(\mathrm{H})$, and flutes (FL). There are in eastern Finland in supra-aquatic areas around remarkable eskers and glaciofluvial gorges this kind of small fluting fields with low profile (e.g., 1-2 m high) and cross-flow direction with respect to the main flow direction, towards the esker chains. Instead of drumlins, the formation of all these landforms must be a late phenomenon and partly simultaneous. It seems that flutes were born on the last of these landforms under moving ice at the same time when there was a strong glaciofluvial activity which accelerated locally the ablation rate and enabled the flow of ice towards the esker chain (ㄷ National Land Survey).

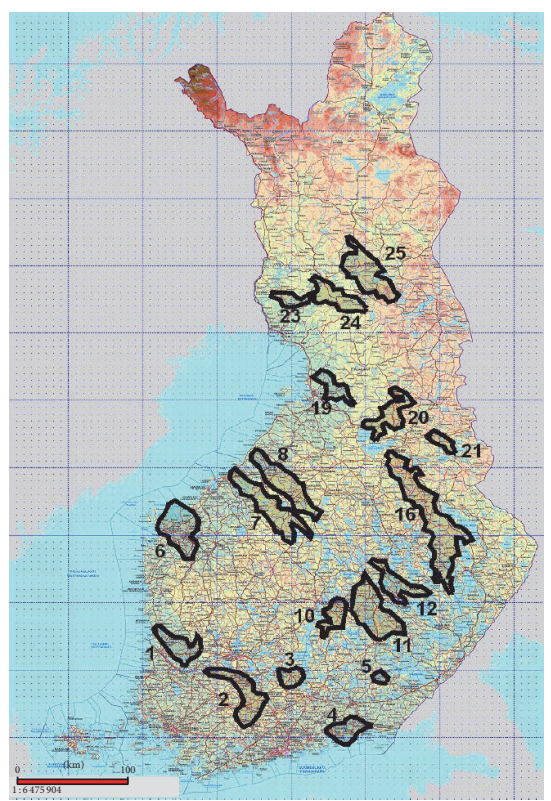

FIGURE 18: Glaciotectonic features occur noticeably in these hummocky moraine fields with original field numbers. The fields are presented as modified after Mäkinen et al. [22]. Subglacial thrust features are quite widely spread in Finland.

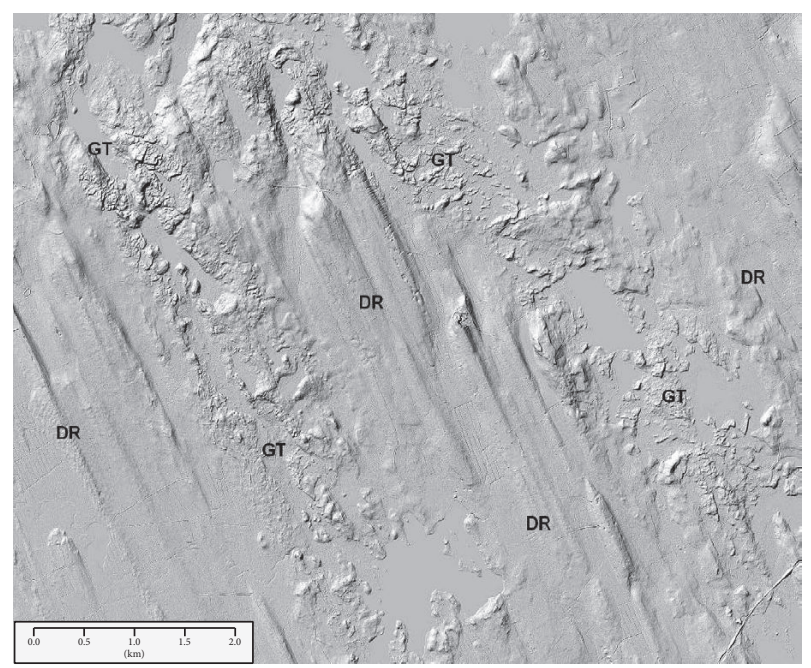

FIGURE 19: Within main ice lobes or streams the glaciated terrain is often divided into smooth looking, abrasive drumlin highlands and into rough erosional lowland zones, where the erosion has happened firstly by glaciotectonism and plucking. Elevation differences between high and low zones are quite small, at most cases $5-50 \mathrm{~m}$. $\mathrm{GT}=$ glaciotectonic zone. $\mathrm{DR}=$ drumlin field. Pieksämäki, southern Savonia (Map sheet N4344F, H; (C) National Land Survey).

Presumably, there were zones at the base of the glacier, where cold and warm conditions alternated at intervals, which resulted in favorable conditions for plucking and the formation of a fragmented topography of glaciotectonic deformation. Perhaps this happened in some areas simply so that the inner cold/warm transition zone shifted gradually towards the ice divide $[29,40]$. Then rough radial zones can represent areas, which for a long time were cold and then at intervals warm. But more probably some cold zones developed for a time in certain places also nearer ice-margins at a fairly late stage. A cold margin is one solution to these questions, but the climate should be too warm and water depth too much for that in many times and in many areas (cf. $[19,20]$ ). Glaciotectonic deformation seems quite a late phenomenon in most places because it has there deformed deglacial landforms, but, in some other areas, it can also be older phenomenon. In order to solve these problems in a convincing manner, a lot more research is required and these questions are partly beyond the purpose of this study.

\section{Conclusions}

After a visual survey of the digital elevation model it can be stated that the features of secondary glacial deformation and glaciotectonism are surprisingly widespread in the morainic landscapes of Finland. These features can be classified as deformational or glaciotectonic, because they are formed by partial deformation of the landforms in the past already born and because the deforming agent was moving glacier [6]. Five types of mostly erosional glaciotectonic landforms were recognized: (1) plucked lee side, (2) hill-hole pair, (3) fanlike and transverse edges of plucked depressions, (4) sporadic 
plucked hollows, and (5) deformational or glaciotectonic mound or ridge. This classification is purely morphological and there is no demand for $25 \%$ portion of glaciotectonised material (cf. [7]). These are slightly different, presumably mostly subglacial, erosional, and much smaller landforms than those in general ice-marginal glaciotectonic landforms, which have presented mainly for more terminal areas of the former ice sheets: hill-hole pairs, composite ridges, mega blocks, push moraines, and cupola hills [4].

There are in literature quite few observations of now recognized landforms, specially what is considered erosional features. Mainly some lee side scarps, hill-hole pairs, marginal moraines, and ribbed moraines are mentioned, which can be considered some category of deformational and glaciotectonic features presented in this study. Finland is located in the central areas of glaciations, where there is virtually no thought to occur notable glaciotectonic effect [17]. Lidarbased interpretation of morainic landforms reveals that block plucking or glaciotectonism of moraines must be quite intensive and widespread producing in many areas fragmented morainic topography. The abundance of deglacial block plucking and thrusting related and glaciotectonic features proves that the base of the receding ice sheet was not all over the entire time at the pressure melting point.

\section{Competing Interests}

The author declares that there are no competing interests regarding the publication of this paper.

\section{References}

[1] S. R. Moran, "Glaciotectonic structures in drift," in Till-A Symposium, R. P. Goldthwait, Ed., pp. 127-148, Ohio State University Press, Columbus, Ohio, USA, 1971.

[2] S. R. Moran, L. Clayton, R. L. Hooke, M. M. Fenton, and L. D. Andriashek, "Glacier-bed landforms of the Prairie region of North America," Journal of Glaciology, vol. 25, no. 93, pp. 457476, 1980 .

[3] H. Ruszczynska-Szenajch, "The origin of glacial rafts: detachment, transport, deposition," Boreas, vol. 16, no. 2, pp. 101-112, 1987.

[4] J. S. Aber, D. G. Croot, and M. M. Fenton, Glaciotectonic Landforms and Structures, Kluwer Academic, Dordrecht, The Netherlands, 1989.

[5] J. S. Aber, J. P. Bluemle, J. Brigham-Grette, L. A. Dredge, D. J. Sauchyn, and D. L. Ackerman, "Glaciotectonic data base and mapping of North America," in Glaciotectonics and Mapping of Glacial Deposits, pp. 177-200, Canadian Plains Research Center, Canadian Plains Proceedings 25/1, 1993.

[6] J. S. Aber and A. Ber, Glaciotectonism, vol. 6 of Developments in Quaternary Science, Elsevier, Amsterdam, The Netherlands, 2007.

[7] D. I. Benn and D. J. A. Evans, Glaciers and Glaciation, Arnold, London, UK, 1998.

[8] M. R. Bennett, "The morphology, structural evolution and significance of push moraines," Earth-Science Reviews, vol. 53, no. 3-4, pp. 197-236, 2001.
[9] D. J. A. Evans and J. England, "High arctic thrust block moraines," Canadian Geographer/Le Géographe Canadien, vol. 35, no. 1, pp. 93-97, 1991.

[10] W. O. Kupsch, "Ice-thrust ridges in western Canada," The Journal of Geology, vol. 70, no. 5, pp. 582-594, 1962.

[11] J. Krüger, "Moraine ridges formed from subglacial frozen-on sediment slabs and their differentiation from push moraines," Boreas, vol. 25, no. 1, pp. 57-63, 1996.

[12] M. J. Hambrey, D. Huddart, M. R. Bennett, and N. F. Glasser, "Genesis of 'hummocky moraines' by thrusting in glacier ice: evidence from Svalbard and Britain," Journal of the Geological Society, London, vol. 154, no. 4, pp. 623-632, 1997.

[13] M. Bennet and N. Glasser, Glacial Geology: Ice Sheets and Landforms, Wiley-Blackwell, 2nd edition, 2009.

[14] J. Krüger, A. Schomacker, and Í. Ö. Benediktsson, "Ice-marginal environments: geomorphic and structural genesis of marginal moraines at Mýrdalsjökull," in The Mýrdalsjökull Ice Cap, Iceland. Glacial Processes, Sediments and Landforms on an Active Volcano, A. Schomacker, J. Krüger, and K. H. Kjær, Eds., vol. 13 of Developments in Quaternary Sciences, chapter 6, pp. 79-104, Elsevier Science, Oxford, UK, 2010.

[15] D. J. A. Evans, N. J. P. Young, and C. Ó. Cofaigh, "Glacial geomorphology of terrestrial-terminating fast flow lobes/ice stream margins in the southwest Laurentide ice sheet," Geomorphology, vol. 204, pp. 86-113, 2014.

[16] J. S. Aber, "Model for glaciotectonism," Bulletin Geological Society Denmark, vol. 30, pp. 79-90, 1982.

[17] J. S. Aber and J. Lundqvist, "Glaciotectonic structures in central Sweden and their significance for glacial theory," Géographie Physique et Quaternaire, vol. 42, no. 3, pp. 315-323, 1988.

[18] M. D. Johnson, O. Fredin, A. E. K. Ojala, and G. Peterson, "Unraveling Scandinavian geomorphology: the LiDAR revolution," GFF, vol. 137, no. 4, pp. 245-251, 2015.

[19] P. Möller and T. P. F. Dowling, "The importance of thermal boundary transitions on glacial geomorphology; mapping of ribbed/hummocky moraine and streamlined terrain from LiDAR, over Småland, South Sweden," GFF, vol. 137, no. 4, pp. 252-283, 2015.

[20] P. Sarala, "Ribbed moraine stratigraphy and formation in southern Finnish Lapland," Journal of Quaternary Science, vol. 21, no. 4, pp. 387-398, 2006.

[21] N. Atkinson, D. J. Utting, and S. M. Pawley, "Landform signature of the laurentide and cordilleran ice sheets across Alberta during the last glaciation," Canadian Journal of Earth Sciences, vol. 51, no. 12, pp. 1067-1083, 2014.

[22] K. Mäkinen, J.-P. Palmu, J. Teeriaho, H. Rönty, T. Rauhaniemi, and J. Jarva, Valtakunnallisesti Arvokkaat Moreenimuodostumat, Suomen Ympäristö 14/2007, Ympäristöministeriö, 2007.

[23] A. P. Stroeven, C. Hättestrand, J. Kleman et al., "Deglaciation of Fennoscandia," Quaternary Science Reviews, vol. 147, pp. 91-121, 2016.

[24] N. R. Iverson, "Processes of glacial erosion," in Modern and Past Glacial Environments, J. Menzies, Ed., pp. 131-146, Butterworth/Heinemann, Oxford, UK, 2002.

[25] G. S. Boulton, "Processes of glacier erosion on different substrata," Journal of Glaciology, vol. 23, no. 89, pp. 15-38, 1979.

[26] J. Rastas and M. Seppala, "Rock jointing and abrasion forms on roches Moutonnees, SW Finland," Annals of Glaciology, vol. 2, pp. 159-165, 1981.

[27] M. Krabbendam and T. Bradwell, "Lateral plucking as a mechanism for elongate erosional glacial bedforms: explaining 
megagrooves in Britain and Canada," Earth Surface Processes and Landforms, vol. 36, no. 10, pp. 1335-1349, 2011.

[28] J. Kleman and I. Borgström, "Glacial land forms indicative of a partly frozen bed," Journal of Glaciology, vol. 40, no. 135, pp. 255-264, 1994.

[29] R. L. Hooke, "Water: the key to landforms of the subglacial environment," in Proceedings of the Meeting of the Canadian Quaternary Association (GeoHydro '11), pp. 28-31, Quebec City, Canada, August 2011.

[30] C. Hättestrand and J. Kleman, "Ribbed moraine formation," Quaternary Science Reviews, vol. 18, no. 1, pp. 43-61, 1999.

[31] R. Aario, "Classification and terminology of morainic landforms in Finland," Boreas, vol. 6, no. 2, pp. 87-100, 1977.

[32] M. A. Bouchard, "Subglacial landforms and deposits in central and northern Québec, Canada, with emphasis on Rogen moraines," Sedimentary Geology, vol. 62, no. 2-4, pp. 293-308, 1989.

[33] P. Dunlop and C. D. Clark, "The morphological characteristics of ribbed moraine," Quaternary Science Reviews, vol. 25, no. 1314, pp. 1668-1691, 2006.

[34] P. Dunlop, C. D. Clark, and R. C. A. Hindmarsh, "Bed ribbing instability explanation: testing a numerical model of Ribbed moraine formation arising from couple flow of ice and subglacial sediment," Journal of Geophysical Research: Earth Surface, vol. 113, no. 3, Article ID F03005, 2008.

[35] M. Lindén, P. Möller, and L. Adrielsson, "Ribbed moraine formed by subglacial folding, thrust stacking and lee-side cavity infill," Boreas, vol. 37, no. 1, pp. 102-131, 2008.

[36] C. R. Stokes, M. Margold, and T. T. Creyts, "Ribbed bedforms on palaeo-ice stream beds resemble regular patterns of basal shear stress ('traction ribs') inferred from modern ice streams," Journal of Glaciology, vol. 62, no. 234, pp. 696-713, 2016.

[37] A. Kejonen, "Permafrost and patterned grounds in Finlandperiglacial or something else," Bulletin of the Geological Society of Finland, vol. 69, no. 1-2, pp. 97-108, 1997.

[38] J.-P. Palmu, "Sedimentary environment of the second Salpausselkä ice marginal deposits in the Karkkila-Loppi area in southwestern Finland," Report of Investigation 148, Geological Survey of Finland, Espoo, Finland, 1999.

[39] M. Seppälä, The Physical Geography of Fennoscandia, Oxford University Press, Oxford, UK, 2005.

[40] J. Kleman and C. Hättestrand, "Frozen-bed Fennoscandian and Laurentide ice sheets during the Last Glacial Maximum," Nature, vol. 402, no. 6757, pp. 63-66, 1999.

[41] J. Kleman and N. F. Glasser, "The subglacial thermal organisation (STO) of ice sheets," Quaternary Science Reviews, vol. 26, no. 5-6, pp. 585-597, 2007.

[42] C. R. Stokes, C. D. Clark, O. B. Lian, and S. Tulaczyk, "Ice stream sticky spots: a review of their identification and influence beneath contemporary and palaeo-ice streams," Earth-Science Reviews, vol. 81, no. 3-4, pp. 217-249, 2007.

[43] C. R. Stokes, O. B. Lian, S. Tulaczyk, and C. D. Clark, "Superimposition of ribbed moraines on a palaeo-ice-stream bed: implications for ice stream dynamics and shutdown," Earth Surface Processes and Landforms, vol. 33, no. 4, pp. 593-609, 2008. 

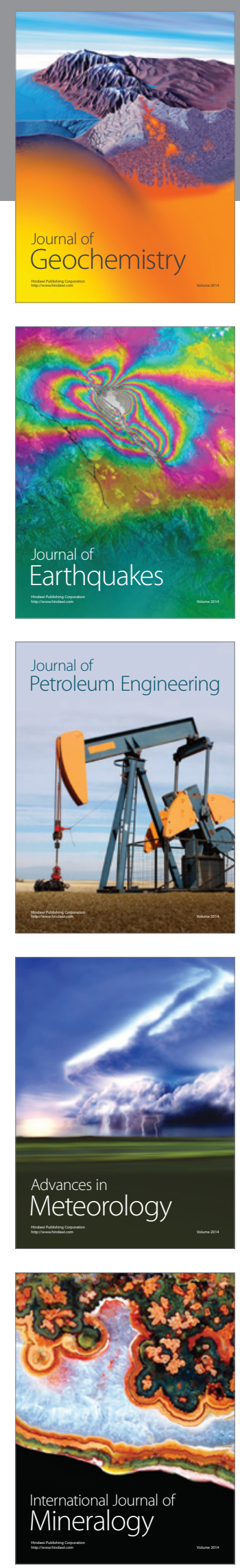
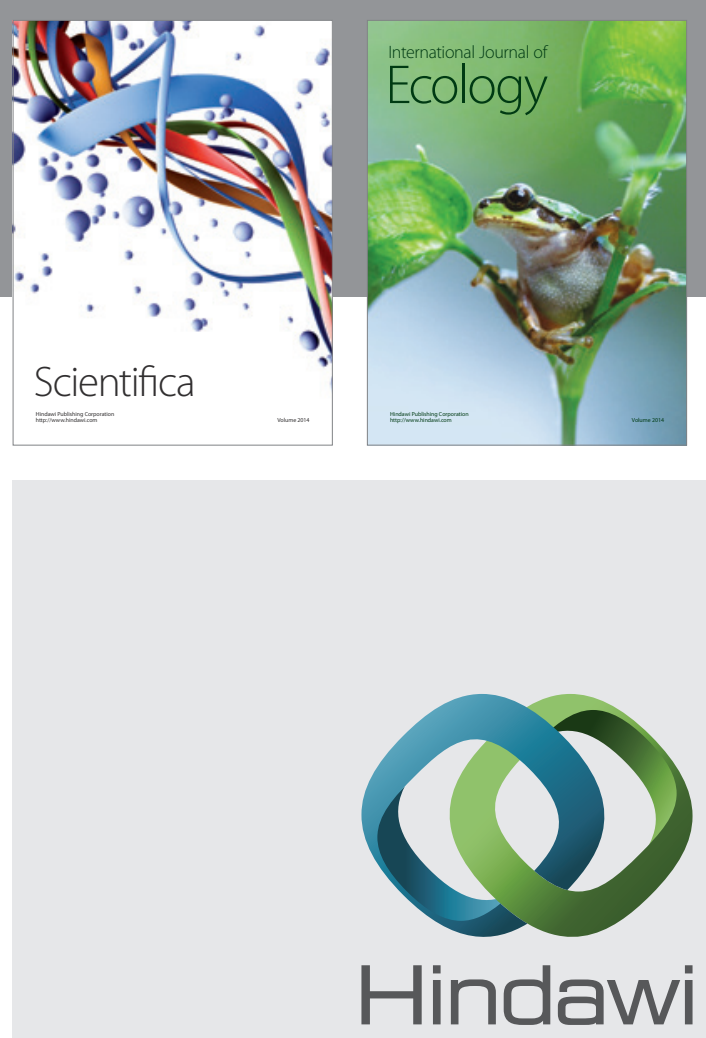

Submit your manuscripts at

http://www.hindawi.com
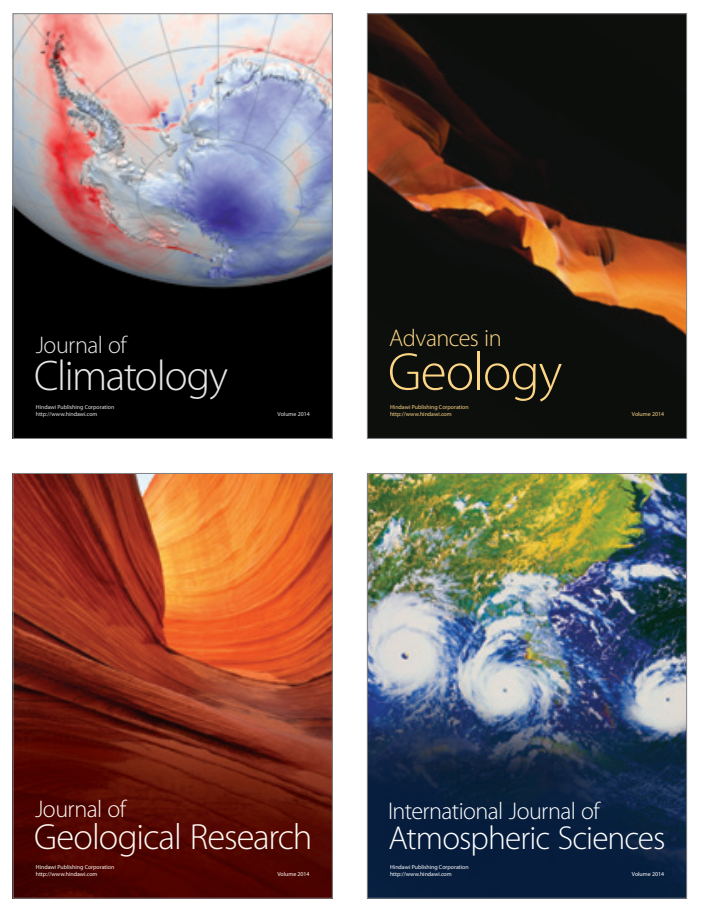

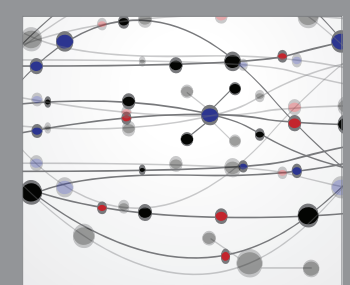

The Scientific

\section{World Journal}
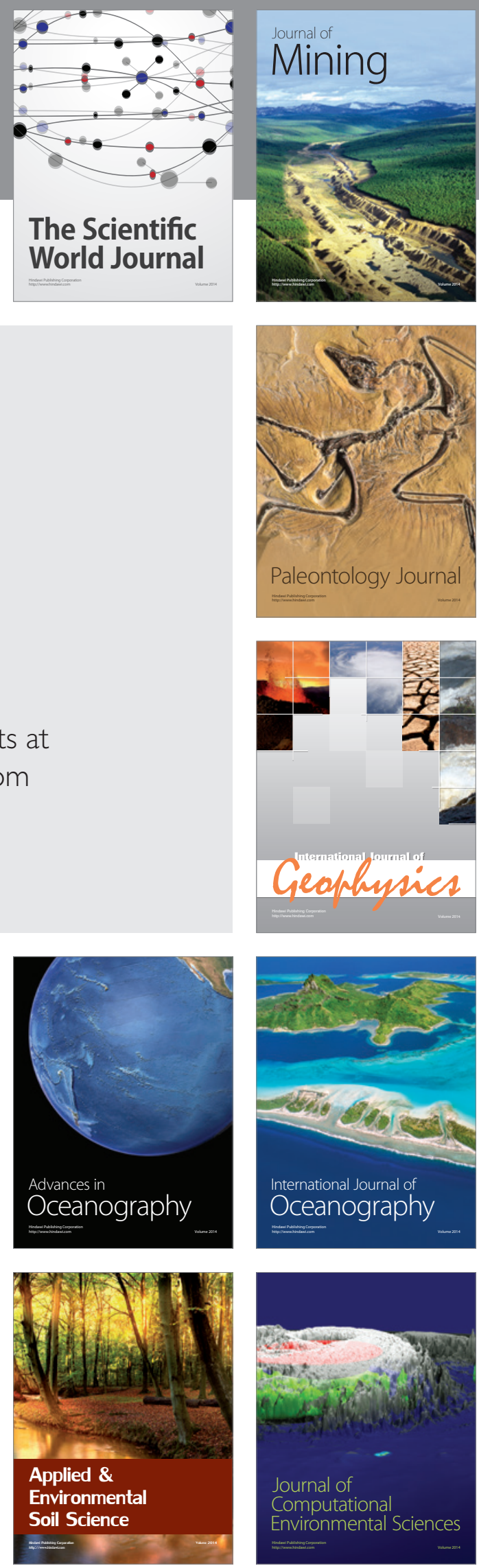